\title{
Macrofaunal community structure and sulfide flux at gas hydrate deposits from the Cascadia convergent margin, NE Pacific
}

\author{
Heiko Sahling ${ }^{1, *}$, Dirk Rickert $^{1}$, Raymond W. Lee $^{2}{ }^{2}$ Peter Linke $^{1}$, Erwin Suess ${ }^{1}$ \\ ${ }^{1}$ GEOMAR Forschungszentrum für Marine Geowissenschaften, Wischhofstraße 1-3, 24148 Kiel, Germany \\ ${ }^{2}$ School of Biological Sciences, Washington State University, Pullman, Washington 99164-4236, USA
}

\begin{abstract}
Gas hydrates occur at the sediment surface on the southern summit of Hydrate Ridge, Cascadia convergent margin. The hydrates are found in mounds several meters in diameter and up to $2 \mathrm{~m}$ high, and are covered by sediment and mats of the filamentous sulfur-oxidizing bacteria Beggiatoa. The mounds are surrounded by vesicomyid clams (Calyptogena pacifica, C. kilmeri), which in turn are encircled by solemyid bivalves (Acharax sp.). The zonation pattern of 3 species (Calyptogena spp. and Acharax sp., which harbor chemoautotrophic bacteria in their gills, and the chemoautotrophic Beggiatoa), is also reflected in a change in the entire community structure. Beggiatoa, Calyptogena spp. and Acharax sp. are shown to be characteristic species for the different communities. The Beggiatoa community directly overlaying the gas hydrates consists of seep endemic species in high densities: gastropods (Provanna laevis, P. lomana, Pyropelta corymba, Hyalogyrina sp. nov.), bivalves (Nuculana sp. nov.) and polychaetes (Ampharetidae, Polynoidae, Dorvilleidae). Based on pooled samples, the rarefaction curves show a decrease in species diversity in the Beggiatoa and Calyptogena communities. The hydrogen sulfide gradients in the porewater of sediments below the different communities dominated by either Beggiatoa, Calyptogena spp. or Acharax sp. vary by 3 orders of magnitude. The diffusive sulfide flux based on the measured sulfide concentration gradients is highest in Beggiatoa sp. communities $\left(23 \pm 13 \mathrm{~mol} \mathrm{~m}^{-2} \mathrm{yr}^{-1}\right)$, slightly less in Calyptogena communities $\left(6.6 \pm 2.4 \mathrm{~mol} \mathrm{~m}^{-2} \mathrm{yr}^{-1}\right)$, and low in Acharax communities $\left(0.05 \pm 0.05 \mathrm{~mol} \mathrm{~m}^{-2} \mathrm{yr}^{-1}\right)$. The difference in the sulfide environment is a factor influencing the distribution patterns of the chemoautotrophy-dependant and heterotrophic species at the deep-sea sediments containing gas hydrate.
\end{abstract}

KEY WORDS: Gas hydrate $\cdot$ Community structure $\cdot$ Biomass $\cdot$ Diversity $\cdot$ Sulfide $\cdot$ Chemoautotrophy Cold seep

\section{INTRODUCTION}

Hydrogen sulfide, which is frequently found in marine sediments, is an energy source for several groups of symbiont-bearing macrofaunal species that depend, to varying degrees, on chemoautotrophic nutrition (Fisher 1990, Childress \& Fisher 1992, Fiala-Médion: et al. 1993). In organic-rich sediments, e.g. below upwelling systems or at sewage outfalls, hydrogen sulfide is produced by anaerobic degradation of organic matter coupled to sul-

*E-mail: hsahling@geomar.de fate reduction. Chemoautotrophic species such as filamentous sulfur bacteria, or chemoautotrophic symbionts such as of solemyid bivalves make use of the sulfide produced in these environments (Felbeck et al. 1981, Otte et al. 1999). Sulfide-rich sediments exist at hydrothermal vents (Grassle et al. 1985, Juniper et al. 1992) and cold seeps at tectonically active and passive continental margins with hydrocarbon/methane seeps or groundwater seeps (reviews: Hovland \& Judd 1988, Sibuet \& Olu 1998). Gas hydrates close to the sediment surface have been discovered in several such settings, where fluid and gas escape, e.g. in the Sea of Okhotsk (Zonenshayn 
et al. 1987, Ginsburg et al. 1993), in the Gulf of Mexico (MacDonald et al. 1994, Sassen et al. 1998), on the northern Californian continental slope (Brooks et al. 1991), at Hydrate Ridge in the Cascadia convergent margin (Suess et al. 1995, 1999), and at several mud volcanoes in the Barents Sea, the Barbados accretionary complex, and the Carolina continental rise (Paull et al. 1995, Olu et al. 1996, Egorov et al. 1999). When methane hydrates are exposed at or near the seafloor, methane diffuses towards the methane-depleted bottom water (Egorov et al. 1999), generating a continuous energy and carbon supply for the benthic environment. It has long been proposed that hydrogen sulfide is produced by methane oxidation coupled to sulfate reduction (Masuzawa et al. 1992, Wallmann et al. 1997), but the microbial consortium apparently mediating this anaerobic methane oxidation has been identified only recently (Boetius et al. 2000).

The most common species directly reliant on chemoautotrophy recovered from fluid and gas seeping areas at the western continental margin off northern America belong to the bivalve families Vesicomyidae and Solemyidae, pogonophorans including the species Lamellibrachia sp., and the mat-forming bacteria Beggiatoa (Suess et al. 1985, Barry et al. 1996, Levin et al. 2000). All species of the groups investigated have been shown to depend on sulfide-oxidizing metabolism (Nelson \& Jannasch 1983, Fisher 1990). Since chemoautotrophy is dependent on reduced chemical compounds, it can be expected that the chemical environment influences the species distribution. The chemical environment of Beggiatoa at hydrothermal mounds is controlled by variable fluid flow causing changing sulfide supply (Gundersen et al. 1992). Such variable conditions might be tolerable or even necessary for Beggiatoa, as these filamentous sulfur-oxidizing bacteria are shown to oxidize sulfide not only via oxygen, but also via their internally stored nitrate (Fossing et al. 1995, McHatton et al. 1996, Otte et al. 1999). For the vesicomyid species Calyptogena pacifica and C. kilmeri, it was shown that their distribution patterns at cold seeps are linked to the sulfide concentrations in the pore-water environment (Barry et al. 1997). The difference between these species in growth rates and in their physiological capabilities of elevating the sulfide concentrations in their blood probably reflects their adaptation to different environmental conditions (Barry \& Kochevar 1998). The chemical environment of shallow-water solemyid bivalves is characterized by high concentrations of organic matter causing high rates of sulfide input into the sediment (Conway et al. 1992). The habitat of deep-water solemyids which are frequently found at sediments from hydrothermal vents (Juniper et al. 1992, Beninger \& Le Pennec 1997) and cold seeps (Sibuet \& Olu 1998) has not been studied geochemically.
A primary question concerning the community structure is the extent to which heterotrophic species at vents or seeps are vagrants, colonists, or endemics (Carney 1994). Colonists are heterotrophic species attracted to vent or seep sites by the aggregation of chemoautotrophically-derived organic matter, endemics are species never found outside sulfidic environments, and vagrants occur uniformly within and outside vents and seeps. Equally important for the community structure are species which might be excluded from sulfide-rich environments, since hydrogen sulfide is potentially toxic to all metazoans (Vetter et al. 1991). A reduction in macrofaunal diversity and richness as a result of warm fluids rich in sulfide and/or hydrocarbons altered the community structure at hydrothermal mounds in the Guaymas Basin, at the Galápagos mounds and at the $21^{\circ} \mathrm{N}$ site (Grassle et al. 1985, Grassle \& Petrecca 1994, Petrecca \& Grassle 1990). In contrast to hydrothermal vent sites, the diversity of infauna was not reduced in vesicomyid clam beds around methane seeps of the Californian continental slope (Levin et al. 2000).

At the Cascadia convergent margin, venting of fluids and gas and the occurrence of methane hydrate deposits has been well documented (Suess et al. 1985, 1999, Kulm et al. 1986, Linke et al. 1994). The water depth and temperatures place the hydrate deposits on the seafloor close to their stability limit, potentially providing large amounts of methane by destabilization of gas hydrates in addition to the continuous supply via diffusion to the methane-depleted bottom water.

Therefore, the objective of this work was to determine the effect on community structure of the unique biogeochemical environment generated by the gas hydrate deposits on the seafloor. The composition, abundance, biomass and diversity of macrofauna at the gas hydrate deposits, the communities surrounding these sites and reference sites are compared in order to answer the question: do gas hydrate deposits on the seafloor support a distinct macrofaunal assemblage?

Hydrogen sulfide concentrations of the pore water were examined to answer the question: is hydrogen sulfide a key factor regulating community structure at seeps? This question is applied to 2 groups: chemoautotrophy-dependent species (Beggiatoa, chemoautotrophic symbioses), which depend directly on sulfide; and heterotrophic species, which tolerate but do not directly benefit from sulfide.

\section{MATERIALS AND METHODS}

Observations and sampling. Visual observations of the seabed and its epibenthic communities were made during dives with DSV 'Alvin' during RV 'Atlantis' Cruise AT3-35b (Torres et al. 1999) and deployments 
of the Ocean Floor Observation System during RV 'Sonne' Cruise SO143 (Bohrmann et al. 2000). Sediment and organisms were sampled during Cruise SO143 with a video-controlled multicorer (TV-MUC). The TV-MUC was equipped with up to 8 core tubes of $50 \mathrm{~cm}$ length and $10 \mathrm{~cm}$ inner diameter. Sediments taken by multicorer were transferred to the cold room, sampled and processed at an in situ temperature of about $4^{\circ} \mathrm{C}$.

Biological studies. For macrofauna ( $>0.5 \mathrm{~mm}$, excluding Crustacea, Nematoda) studies, the uppermost $1 \mathrm{~cm}$ of the sediment from the TV-MUC cores was left in one piece while the rest was processed through $0.5 \mathrm{~mm}$ sieves. The macrofauna were immediately extracted by hand, preserved in $10 \%$ buffered formaldehyde, sorted to the lowest taxonomic level possible, and counted. Biomass was estimated by establishing allometric functions for the frequent species (Mollusca), direct weighing (Ophiuroidae), or estimating biovolumes. The dry mass and ash-free dry mass of mollusks and ophiuroids were determined to estimate the weight of calcareous parts. The dry mass was measured after drying the samples for $24 \mathrm{~h}$ at $60^{\circ} \mathrm{C}$. The ash-free dry mass was determined after igniting for $12 \mathrm{~h}$ at $600^{\circ} \mathrm{C}$. The biomass for the mollusks and ophiuroids is given as wet weight without calcareous parts. Biovolumes were converted to wet mass by applying the general density of $1.13 \mathrm{~g} \mathrm{~cm}^{-3}$ (Feller \& Warwick 1988).

Bacterial symbionts were detected immunologically to distinguish between fauna dependent on chemoautotrophy and those dependent on heterotrophy. The presence of symbionts in deep-frozen specimens were detected using an antiserum that recognizes symbiont glutamine synthetase (Lee et al. 1999).

Geochemical studies. Pore water was extracted from wet sediment segments using a low-pressure nitrogen squeezer and filtering through a $0.2 \mu \mathrm{m}$ cellulose acetate membrane. Hydrogen sulfide was determined spectrophotometrically (Grasshoff et al. 1983). Seawater oxygen concentrations at or near the benthic sampling sites were determined by Winkler titration. Water samples were taken with Niskin bottles.

Sulfide flux estimates. The concentration gradient $(\mathrm{d} C / \mathrm{d} x)$ of hydrogen sulfide drives a diffusive flux $\left(J_{\text {diff }}\right)$ which was calculated using Fick's law of diffusion as modified for sediments (Boudreau 1997):

$$
J_{\text {diff }}=-\phi \cdot D_{\mathrm{s}} \frac{\mathrm{d} C}{\mathrm{~d} x}
$$

where $\phi$ is porosity, and $D_{\mathrm{s}}$ is the diffusion coefficient in the sediment. A more rigorous coupled diffusionadvection model is applied elsewhere (Rickert et al. unpubl. data). $D_{\mathrm{s}}$ was calculated according to the following equation (Boudreau 1997):

$$
D_{\mathrm{s}}=\frac{D_{\mathrm{m}}}{1-\ln \left(\phi^{2}\right)}
$$

with a temperature-dependent molecular diffusion coefficient $\left(D_{\mathrm{m}}\right)$ according to Boudreau (1997):

$$
D_{\mathrm{m}}=\left(m_{0}+m_{1} \cdot T\right) \times 10^{-6}
$$

with $m_{0}=10.4, m_{1}=0.273$ at an in situ temperature of $T=4.2^{\circ} \mathrm{C}$. The concentration gradient was calculated for the depth interval with the greatest concentration change, with porosity values measured (range 0.6 to 0.75 ) or average values applied (0.7). Results are given as average \pm SD ( $n=$ number of samples).

Statistical analyses. All statistical analyses of biological samples were conducted at the family level. Multivariate analyses of community composition were performed by the analyses of similarities (ANOSIM) and multidimensional scaling (MDS) with the software package Primer 4.0 (Clarke \& Warwick, 1994). BrayCurtis similarities were calculated based on fourthroot-transformed biomass data. The abundance/biomass comparison graphs were plotted with Primer 4.0. The species-count data for each station were pooled as classified, and the rarefaction curves were calculated for each class with the software 'Biodiversity Pro'. The non-parametric Kruskal \& Wallis test was performed with Statistica 5.1, the post hoc Nemenyi test followed the procedure given in Lozán (1998).

\section{RESULTS}

\section{Site description}

Gas hydrate deposits were found on the southern summit of Hydrate Ridge at a water depth of 770 m (Fig. 1). At the summit, an area of about $100 \mathrm{~m}$ in diameter consisted of mounds several meters across and up to $2 \mathrm{~m}$ high. The mounds were always covered with a layer of thick orange or white Beggiatoa mats. During seafloor sampling it was evident that the sediments just below the bacterial mats contained high amounts of gas hydrates (Fig. 2). The bacteria-covered mounds were surrounded by vesicomyid clam colonies dominated by Calyptogena pacifica and C. kilmeri. Most of the clams in the colonies, which were a few square meters in diameter, were alive. Adjacent to the clam fields, the sediment-dwelling solemyid bivalve Acharax sp. was recovered. The extent of area inhabited by Acharax sp. is unknown, but this species was only found regularly from a few tens of centimeters up to $1 \mathrm{~m}$ away from the vesicomyid clams.

The oxygen concentration in the bottom water at the southern summit of Hydrate Ridge was low (0.4 to $0.47 \mathrm{ml} \mathrm{l}^{-1}$ ). The reference sites in the basin north-east of Hydrate Ridge are located in water depths of $1000 \mathrm{~m}$ 


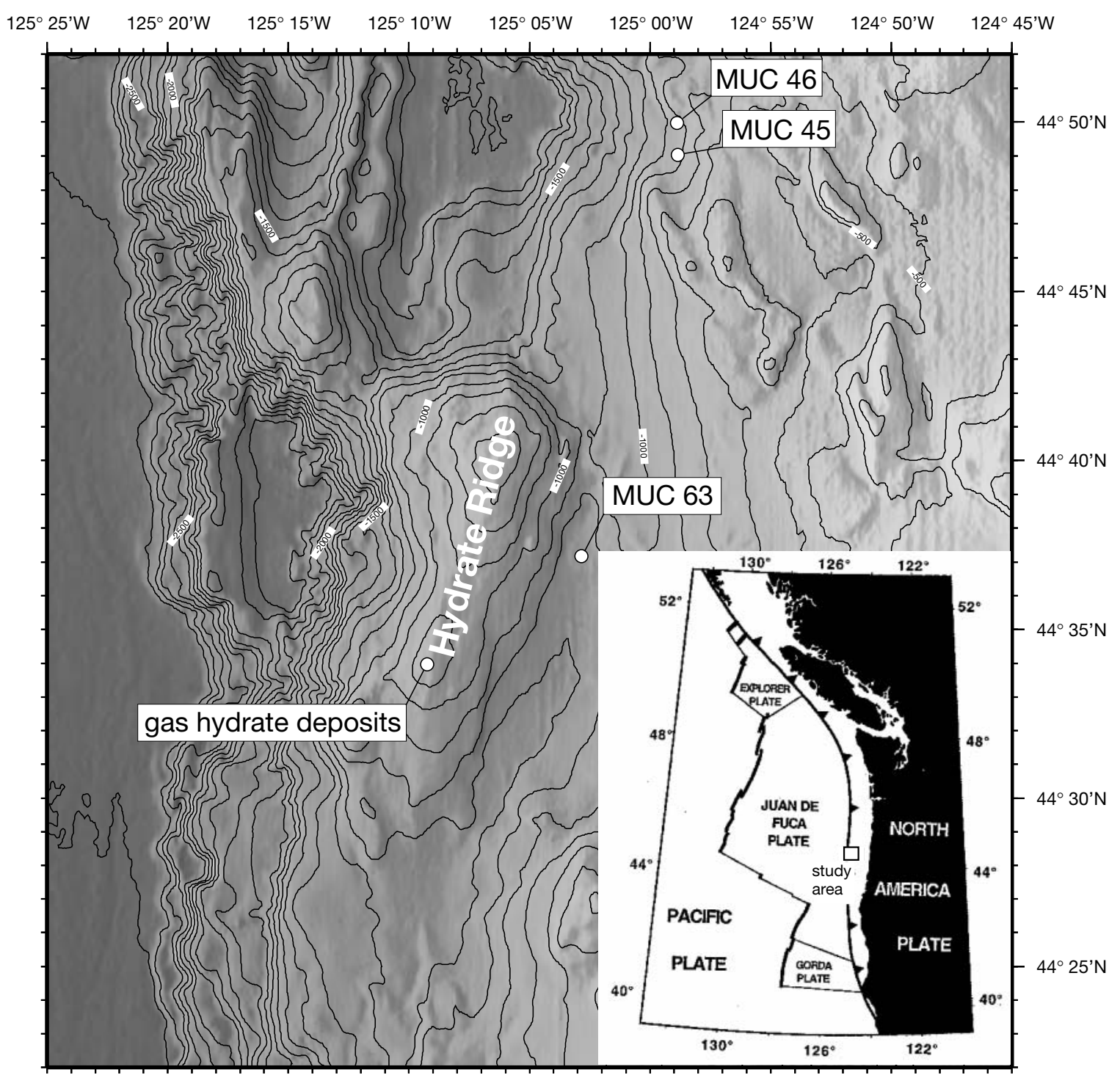

Fig. 1. Locations of gas hydrate deposits on Hydrate Ridge and reference stations without fluid- or gas-seepage (MUC 45, 46, 63) at the Cascadia convergent margin

(MUC 45, 46) and $1250 \mathrm{~m}$ (MUC 63) with slightly higher oxygen concentrations $\left(0.43\right.$ to $0.49 \mathrm{ml} \mathrm{l}^{-1}$ and $0.65 \mathrm{ml} \mathrm{l}^{-1}$, respectively) than the study site.

\section{Classification into Beggiatoa, Calyptogena and Acharax communites}

A total of 56 TV-MUC cores were taken and analyzed either for the macrofaunal composition $(n=38)$ or for sulfide concentrations in the porewater $(n=18)$. Each core was classified according to the dominance of characteristic species: Beggiatoa, Calyptogena or Acharax. This classification scheme was readily applied because in most cases only 1 of the 3 speci- mens was present. In only 3 samples, were vesicomyids ( $<5 \mathrm{~mm}$ in length) found with thick Beggiatoa mats. These cases were classified as belonging to the Beggiatoa community. Occasionally a small proportion of the sediment surface of cores inhabited by 1 or more vesicomyid clams was covered by Beggiatoa filaments. These cores were classified as belonging to the Calyptogena community. In 3 instances, Calyptogena spp. and Acharax sp. occurred together, but the biomass was dominated clearly by 1 of the 2 species and therefore these cores were assigned to the respective community.

The physical properties of the sediment were highly variable due to changes in water content and the occurrence of shell debris as well as authigenic car- 


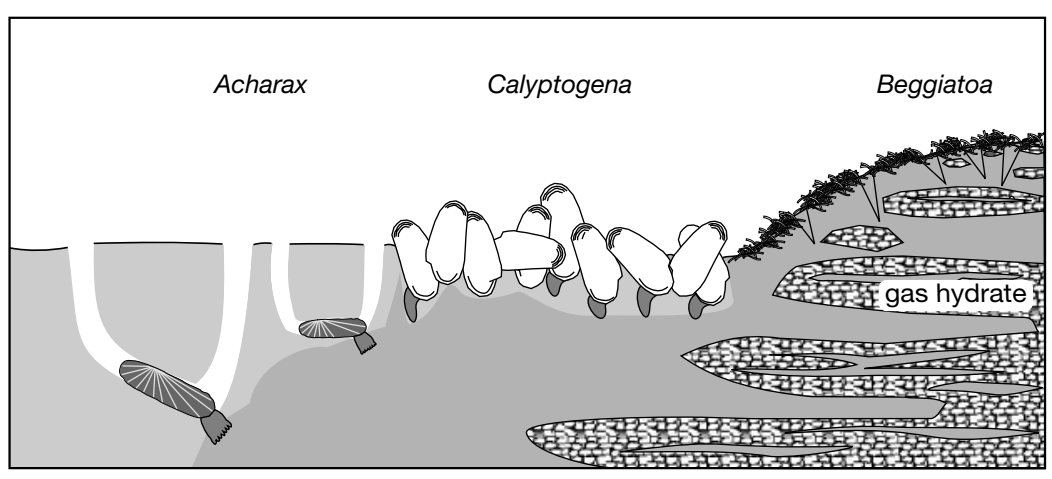

Fig. 2. Schematic illustration of Acharax, Calyptogena and Beggiatoa distribution at the gas hydrate deposits on Hydrate Ridge. The mounds covered by the filamentous mat-forming sulfur bacteria Beggiatoa consist of gas hydrates. Darker shaded areas indicate sediments with high hydrogen sulfide concentrations

bonate fragments. The communities dominated either by Beggiatoa, Calyptogena spp. or Acharax sp. were not obviously correlated with the sediment properties.

The macrofaunal composition was analyzed in 8 Beggiatoa, 9 Calyptogena spp. and 7 Acharax sp. dominated cores (Tables 1 to 3 ). Three cores without any of the characteristic species were collected about $0.5 \mathrm{~m}$ away from the Acharax habitat and were classified as reference cores (Table 4). To further compare the faunal composition to far-off non-seep settings, 11 cores from a sediment-filled fore-arc basin in water depths of 1000 to 1250 m, north-east of Hydrate Ridge, were collected as well.

The classification of the cores into Beggiatoa, Calyptogena, Acharax, and reference communities a priori provided the opportunity of testing whether or not the entire macrofaunal composition differs between these groups. After excluding the characteristic species (Vesicomyidae, Solemyidae) from the species/sample list we applied a multivariate analysis of similarity (1-way ANOSIM). With this statistical method, we could show that the 4 community types differ from each other based on a global test score (global $\mathrm{R}=$ 0.419, $p<0.001$ ). In a paired test, we further showed that the difference between the communities was significant at the 95\% confidence level (Bonferroniadjusted). The paired test additionally indicated that communities adjacent to each other (BeggiatoaCalyptogena, Calyptogena-Acharax and Acharax-nonseep) were more similar to each other (significance levels $=4.5,0.5,3.0 \%$, respectively) than communities farther apart from each other (Beggiatoa-Acharax, Beggiatoa-non-seep, Calyptogena-non-seep; significance levels $=0.0 \%$ ). Such a pattern is characteristic of a gradual change visualized by 2-dimensional MDS ordination (Fig. 3); however, the samples characterized by Beggiatoa, Calyptogena or Acharax form distinct clusters. In this plot, the reference sites from the basin north-east of Hydrate Ridge were excluded because of their very high dissimilarity.

\section{Macrofaunal composition}

The variable abundance of species of the families Ampharetidae, Dorvilleidae, Polynoidae, Hyalogyrinidae, Provannidae, Pyropeltidae and Nuculanidae caused the very high density differences (individuals per $78.5 \mathrm{~cm}^{2}$ core) between Beggiatoa, Calyptogena, and Acharax communities, with average values of 70,39 , and 10 , respectively, compared to 2.6 at the non-seep reference site (Tables 1 to 4 ). The differences in abundance between these sites were significant (Kruskal-Wallis test: $H=29.7, \mathrm{p}<0.01$ ). The post hoc Nemenyi test confirmed that macrofaunal abundance at both the Beggiatoa and Calyptogena communities differed significantly $(\mathrm{p}<0.01)$ from the non-seep reference community.

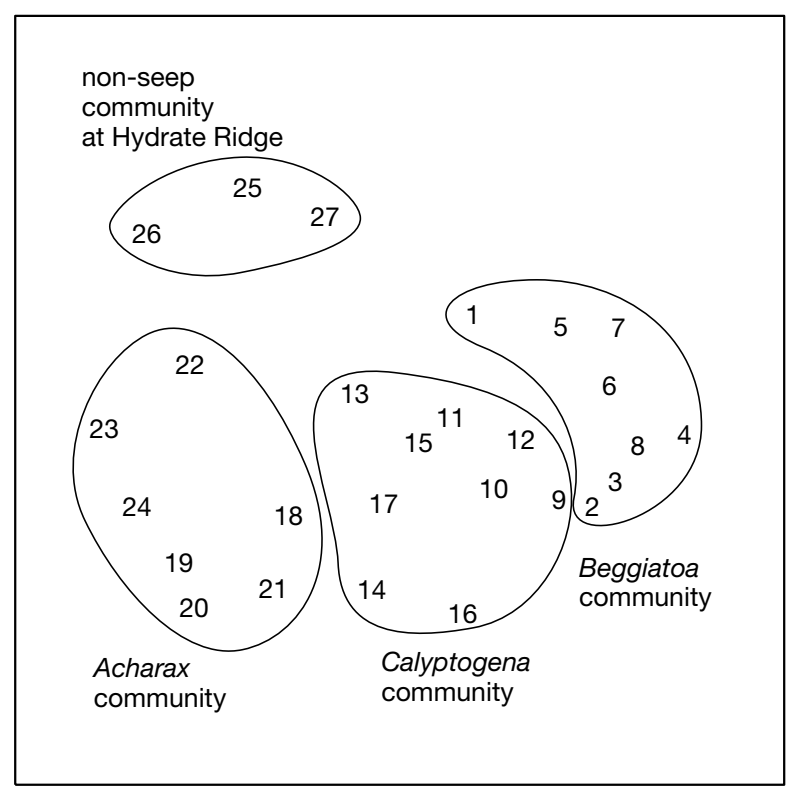

Fig. 3. Two-dimensional MDS ordination plot of macrofauna from sediments at Hydrate Ridge. The samples (numbered as in Table 1) were classified into 4 groups by the presence of Beggiatoa, Calyptogena spp., Acharax sp. or the absence of all 3 species. The distribution pattern of the samples in the MDS plot visualizes the gradual change of the macrofaunal assemblages between the different communities. Stress value was 0.17 
The differences in total biomass of the Beggiatoa, Calyptogena, and Acharax communities compared with the reference sites were significant (KruskalWallis test: $H=17.73, \mathrm{p}<0.01)$. The differences were caused by significant biomass differences between the Calyptogena community and the reference sites, as revealed by a post hoc Nemenyi test $(p=0.01)$. The average biomass of macrofauna (wet weight without calcareous parts) in the Calyptogena community (162 $\mathrm{g} \mathrm{m}^{-2}$ ) was an order of magnitude higher than the biomass at the non-seep sites $\left(10 \mathrm{~g} \mathrm{~m}^{-2}\right)$.

\section{Macrofaunal diversity}

Because of the limited amount of samples, rarefaction curves were calculated based on pooled samples for Beggiatoa, Calyptogena and Acharax communities as well as for the reference sites (Fig. 4). Diversity was lowest in the Beggiatoa community and increased in the Calyptogena community. The diversity of the Acharax community was similar to the diversity of the reference sites.

\section{Chemoautotrophic symbiosis versus heterotrophic species}

An enzyme marker diagnostic of chemoautotrophic symbiosis was observed in Calyptogena pacifica, $C$.

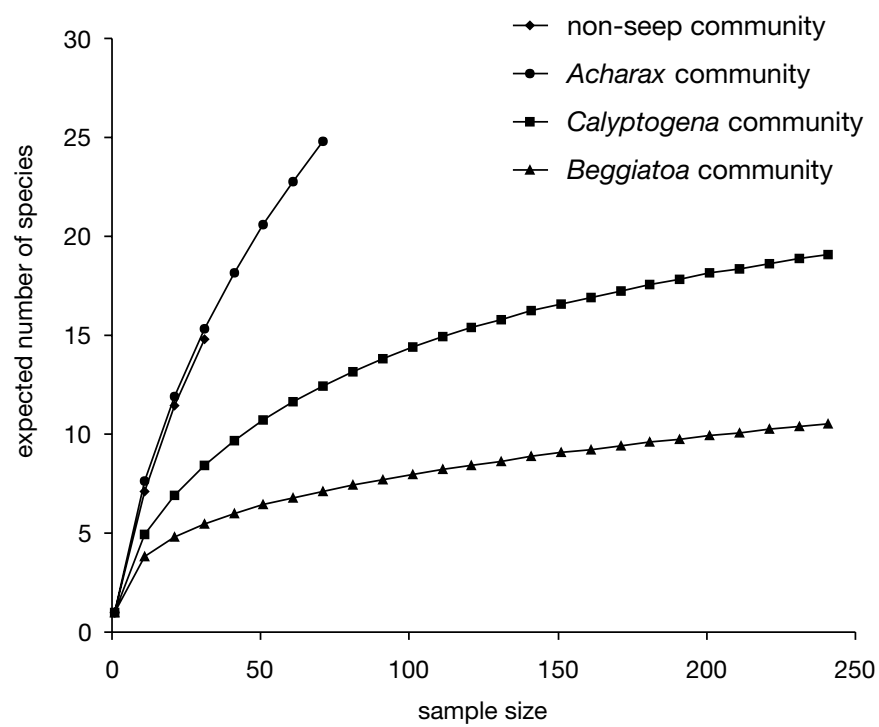

Fig. 4. Rarefaction curves showing the expected number of macrofaunal species for a given sample size in pooled samples from the gas hydrate deposit area on Hydrate Ridge and the reference stations without seepage. Full specific names as in Fig. 3 legend kilmeri, Vesicomya stearnsii and Acharax sp. All species tested positive for the presence of bacterial glutamine synthetase, which is involved in chemoautotrophic assimilation of inorganic nitrogen. In Provanna laevis, P. lomana, Nuculana sp. and a pool of 5 to 10 specimens of Ampharetidae and Polynoidae, bacterial glutamine synthetase was not detected. Although these results need to be confirmed by other techniques, we will consider only the vesicomyid and solemyid bivalves as chemoautotrophic symbiosis. The biomass (wet weight without calcareous parts) of chemoautotrophic bivalvia was highest within the vesicomyid clam fields (149 $\mathrm{g} \mathrm{m}^{-2}$ ) and the solemyid bivalve habitat (111 $\mathrm{g} \mathrm{m}^{-2}$ : Table $5 \mathrm{a}$ ). The biomass in the Beggiatoa community was clearly dominated by the chemoautotrophic filamentous bacteria; the chemoautotrophic bivalvia biomass was insignificant. The biomass of the heterotrophic macrofauna was highest in the Beggiatoa community because of the abundance of the bivalve Nuculana sp. and the gastropods. The biomass of heterotrophic macrofauna was also high in the Acharax community, as a result of high polychaete biomass.

\section{Endemic versus colonist species}

Species which occurred exclusively in the Beggiatoa, Calyptogena or Acharax communities and/or have close taxonomic relationship to species known to be endemic at other vents or seeps were classified as endemic species. Of the 36 families identified in this study, 9 were found exclusively at the seeps. Besides the Vesicomyidae and Solemyidae at the Hydrate Ridge site, a new species of Nuculana (Nuculanidae) was abundant, which has its closest relative in $N$. grasslei (Allen 1993) described from the hydrothermal vent in the Guaymas Basin (Waller pers. comm.). The gastropod families Provannidae, Pyropeltidae and Hyalogyrinidae, with a new species in the latter family (Warén \& Bouchet 2001), obligatorily occur at seep and vent habitats (Warén pers. comm.). The ampharetid polychaetes were abundant at the hydrate deposits. At least 1 species identified so far (Parvelius uschakovi: Hilbig pers. comm.) is known from the hydrate deposits in the Sea of Okhotsk (Kuznetsov \& Levenstein 1988). Polychaete species in the families Dorvilleidae and Polynoidae were found only at the hydrate deposits, with at least 1 new species of Dorvilleidae (Hilbig et al. unpubl. data) and another species very similar to Ophryotrocha platykephle, also described from the Guaymas Basin hydrothermal mounds (Blake 1985, and pers. comm.).

We grouped the species, distinguishing between heterotrophic seep fauna, heterotrophic non-seep fauna, 


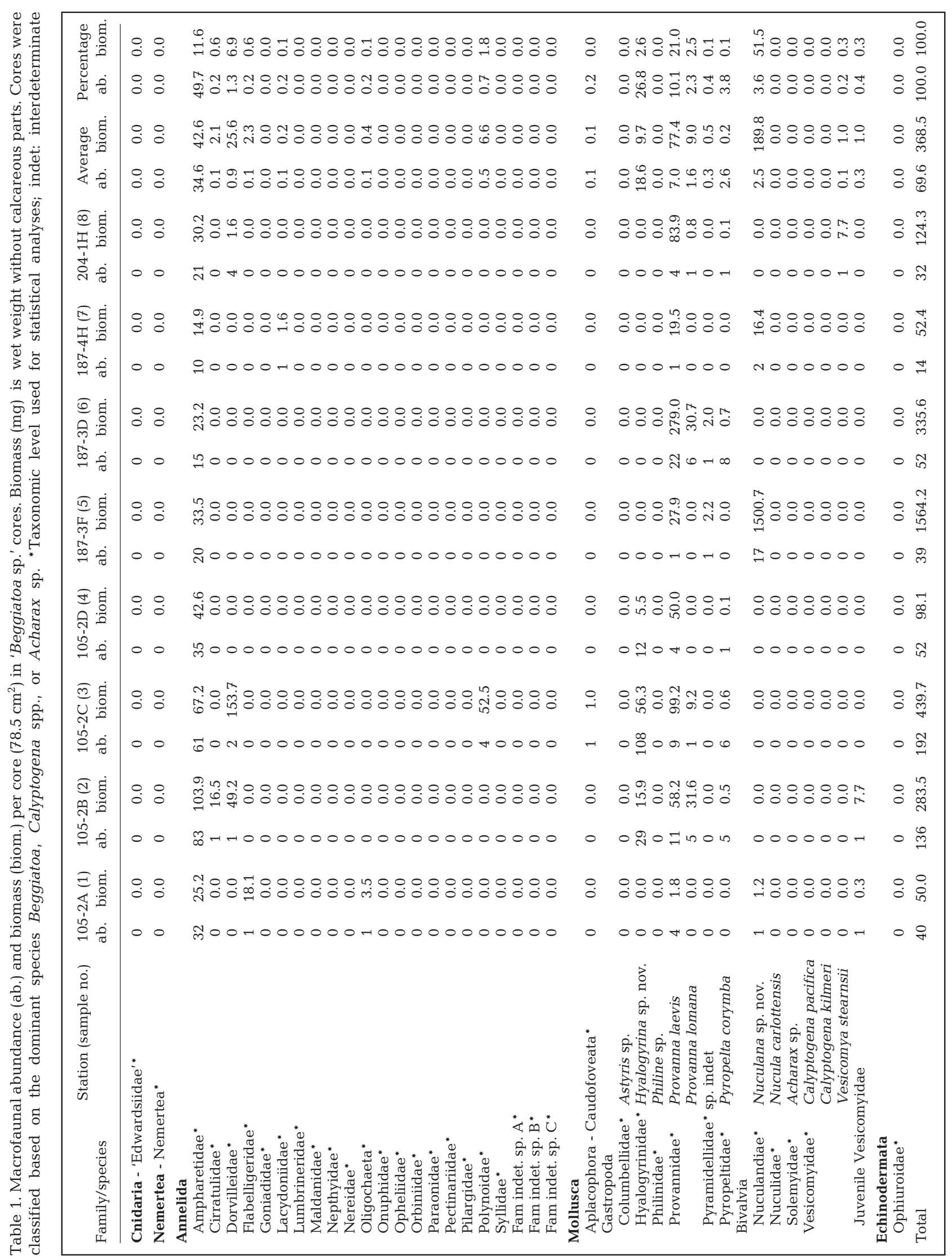




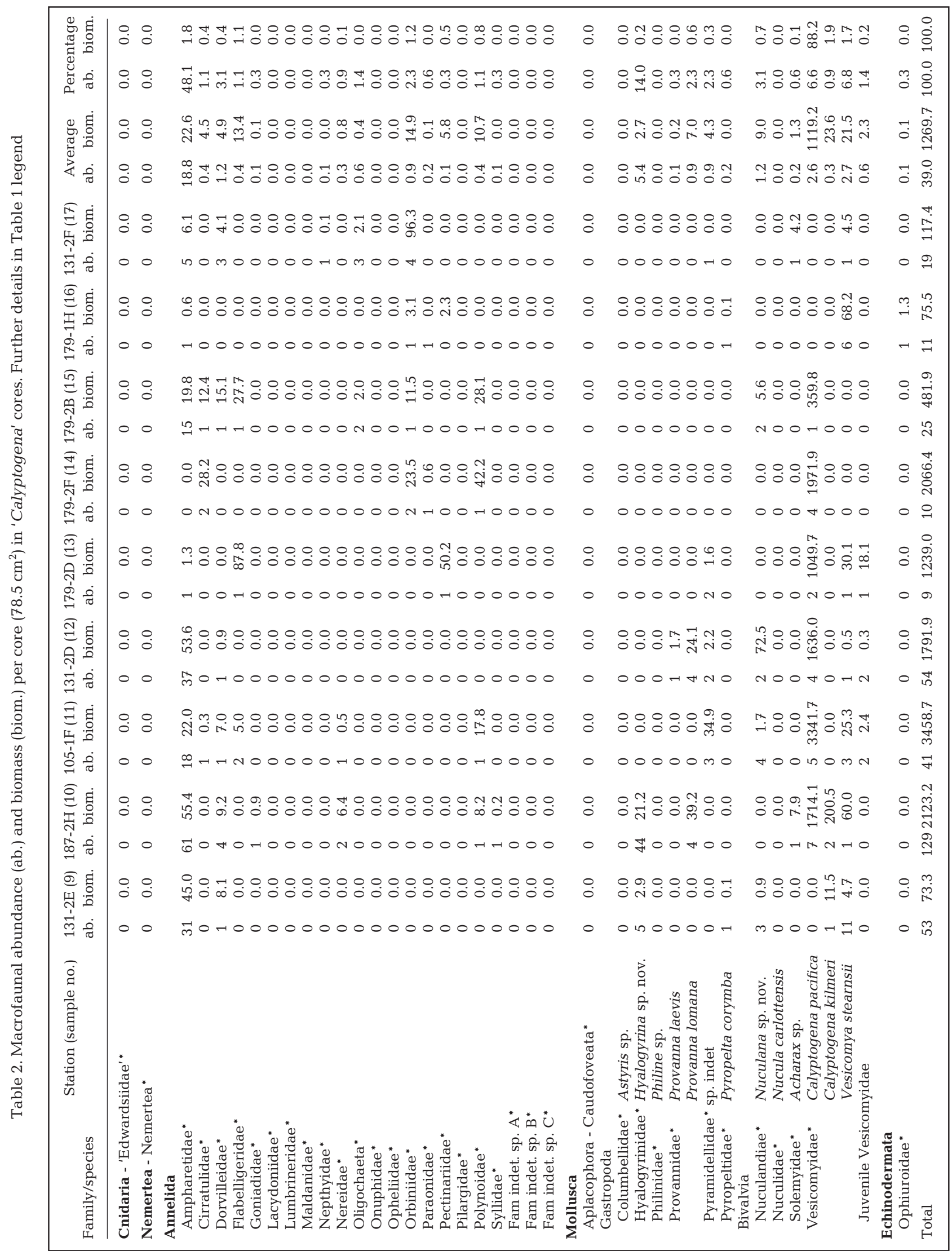




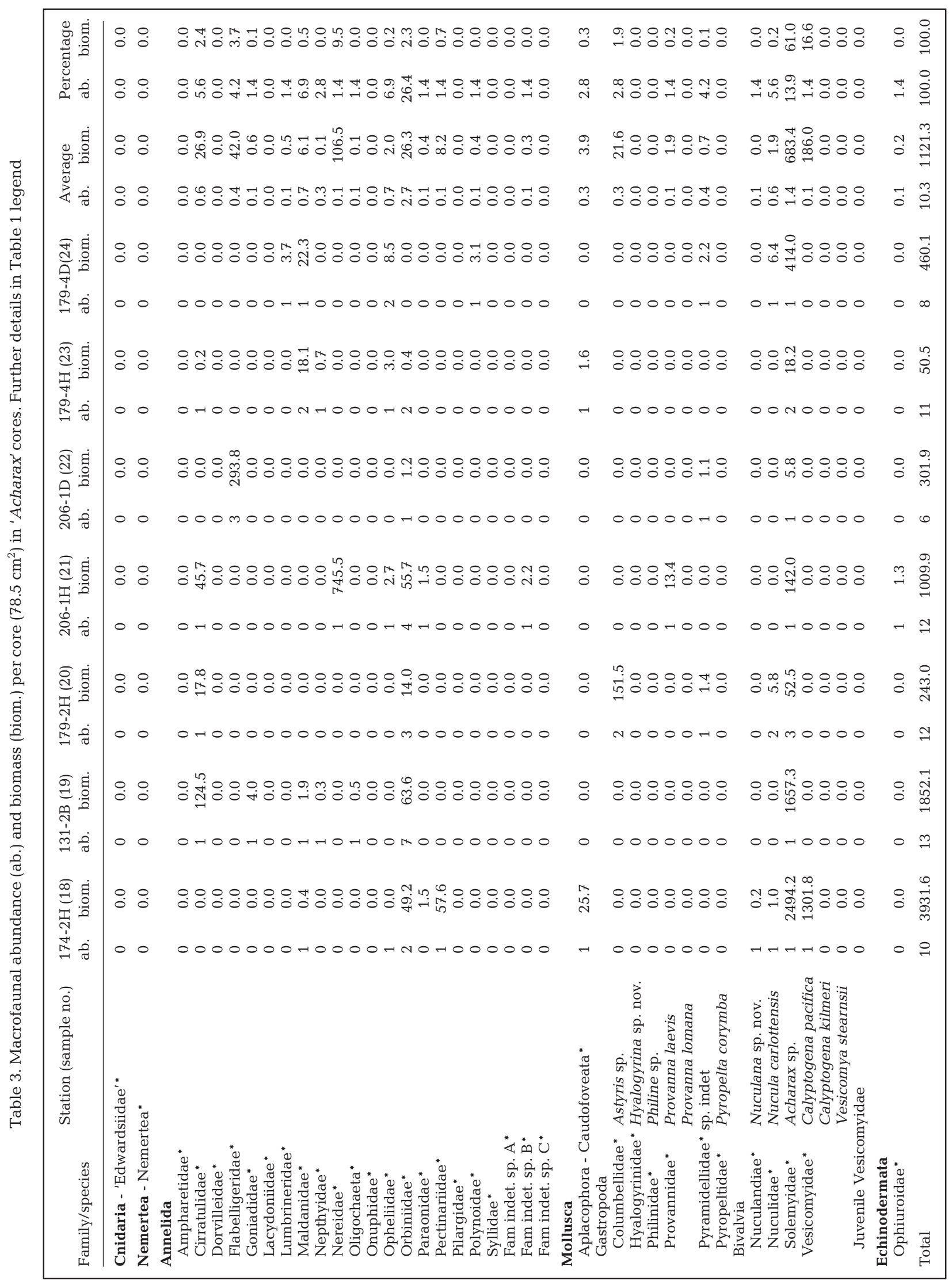




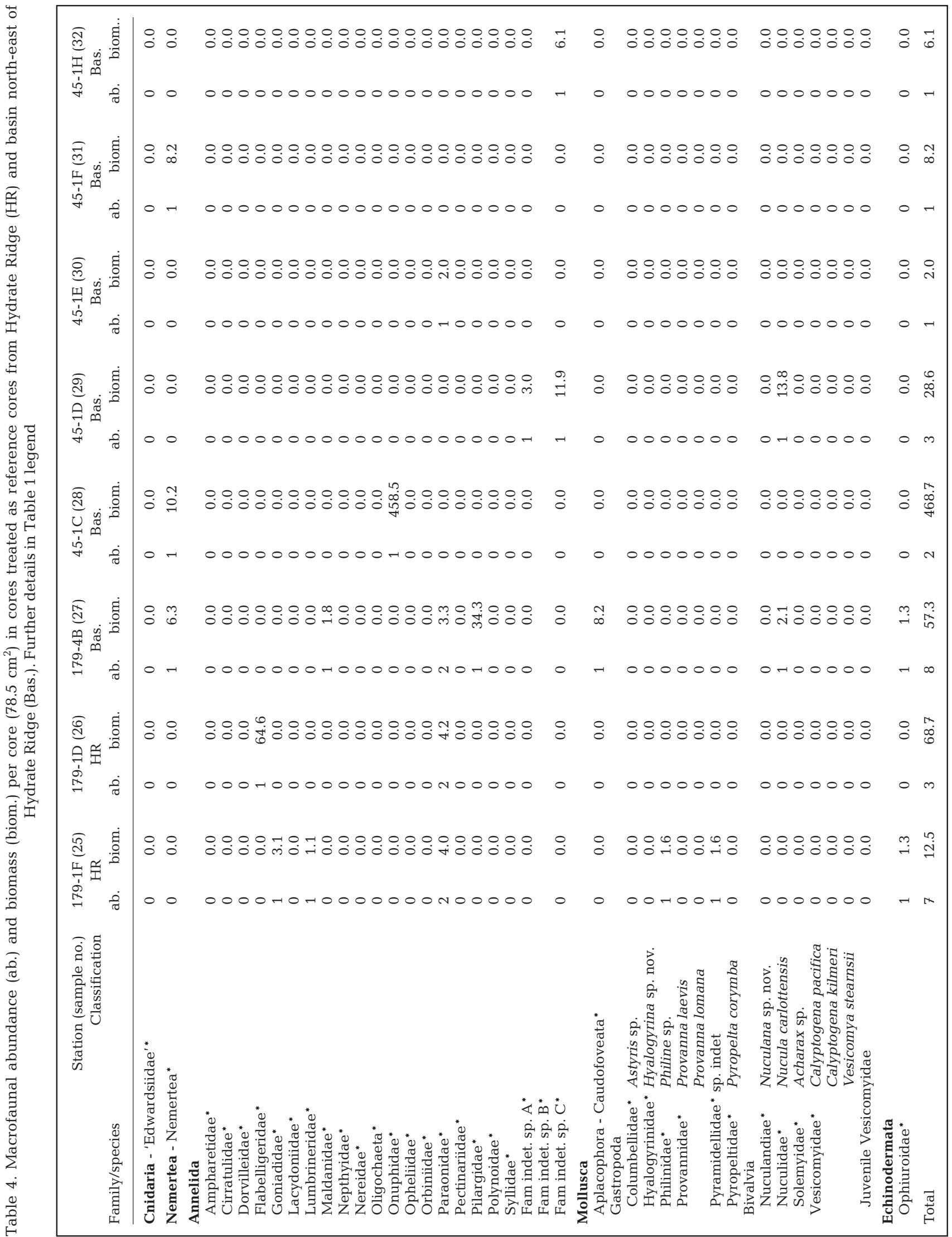




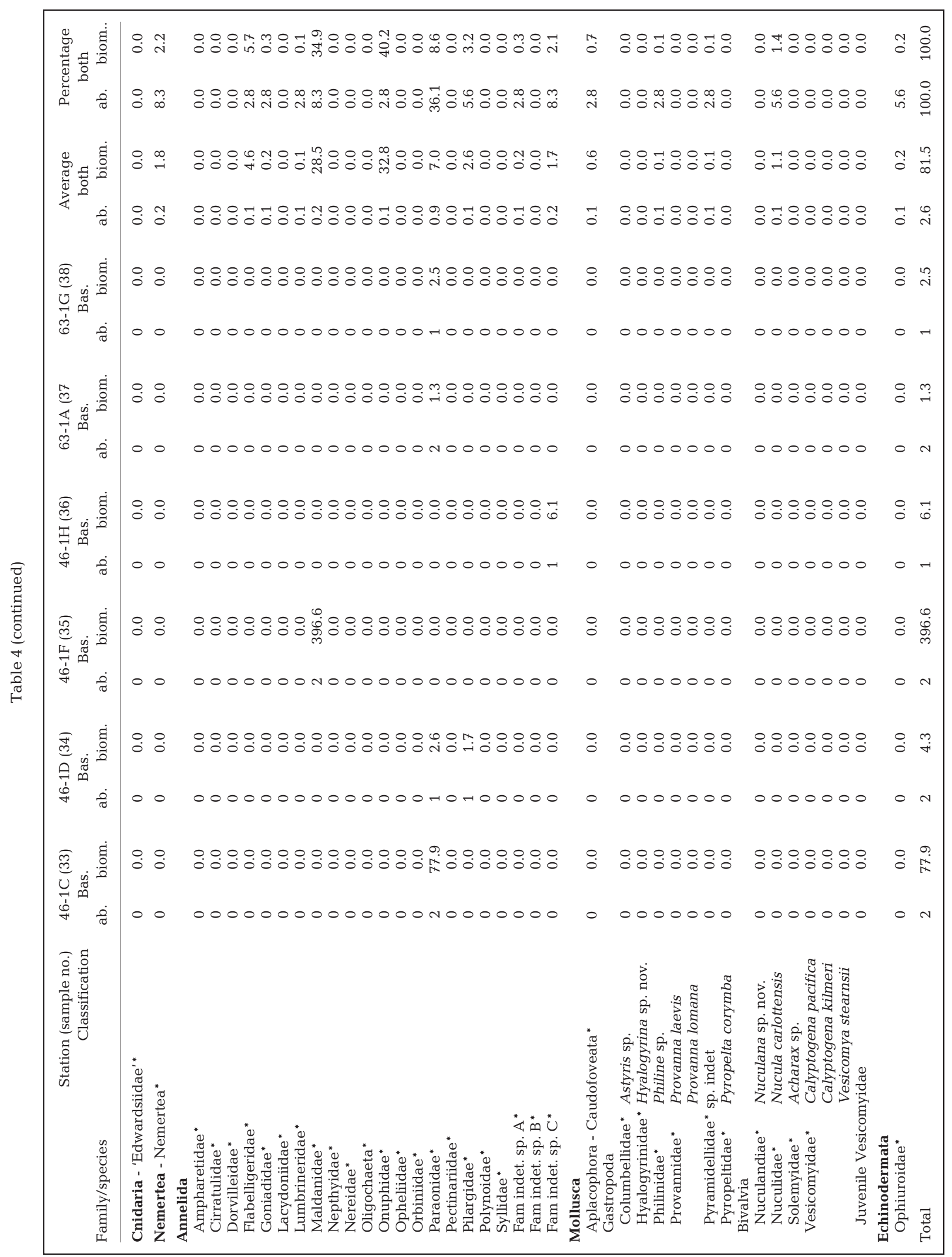




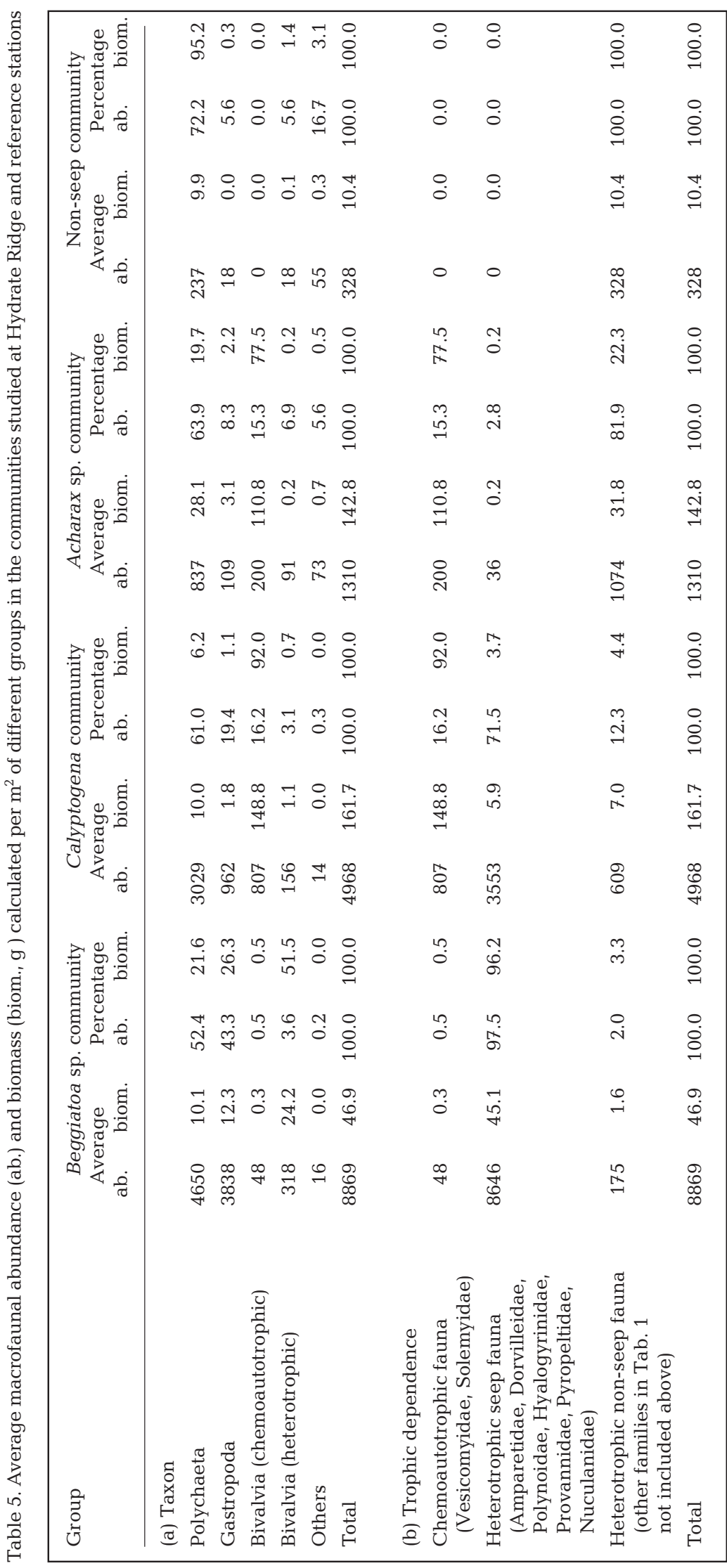

and chemoautotrophy-dependent fauna (Table 5b). This classification allowed us to differentiate between the importance of endemic species (heterotrophic seep fauna) and colonists (heterotrophic nonseep fauna). The biomass of heterotropic non-seep fauna was significantly different between the communities (KrustalWallis test: $H=12.45, \mathrm{p}<0.01$ ). The post hoc Nemenyi test revealed that the biomass was significantly higher in the Acharax than in the Beggiatoa community $(p<0.01)$. The biomass of the heterotrophic seep fauna was significantly different between the Beggiatoa, Calyptogena and Acharax communities (Kruskal-Wallis $H=14.71, \mathrm{p}<0.01$ ). The reason was a significantly higher biomass of seep species in the Beggiatoa community compared to the Acharax community, as shown by the post hoc Nemenyi test $(p<0.01)$.

\section{Abundance/biomass comparison}

The results of abundance/biomass comparison are shown in Fig. 5. At the reference non-seep site, the biomass of the Calyptogena and the Acharax communities was dominated by comparable large species, each represented by few individuals. The biomass curve fell well above the abundance curve on the abundance/biomass comparison plot. In the Beggiatoa community, the specimens were rather similar in size and biomass as indicated by the biomass and abundance curves which were closely coincident.

\section{Hydrogen sulfide concentrations and fluxes}

The sulfide profiles in the underlying sediments were vastly different for each community (Fig. 6). At sites with Beggiatoa sp. mats covering the hydrates, sulfide concentrations reached levels of more than $10 \mathrm{mM}$ in the uppermost centimeters of the sediment, with maximum concentrations exceeding $26 \mathrm{mM}$. In the Calyptogena communities, sulfide levels also increased significantly with 


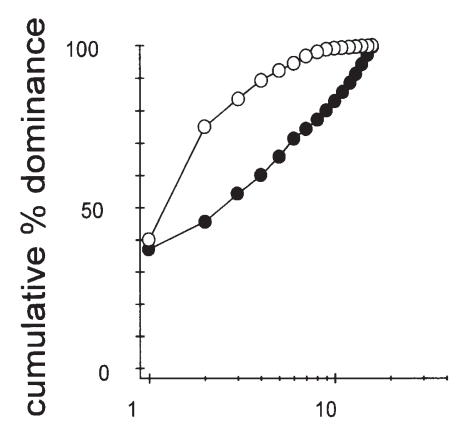

non-seep community

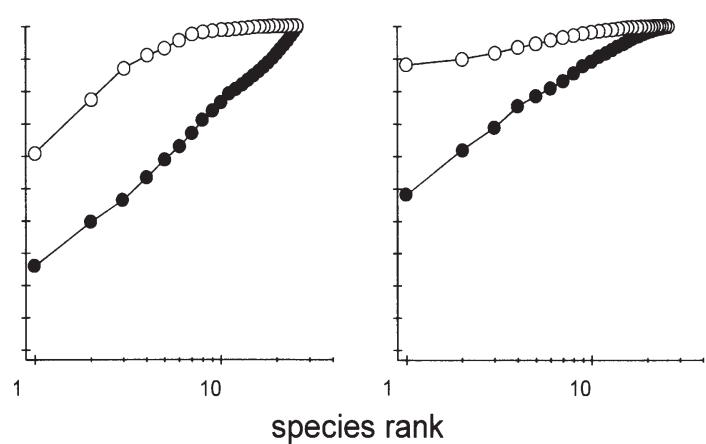

Acharax community
Calyptogena
community

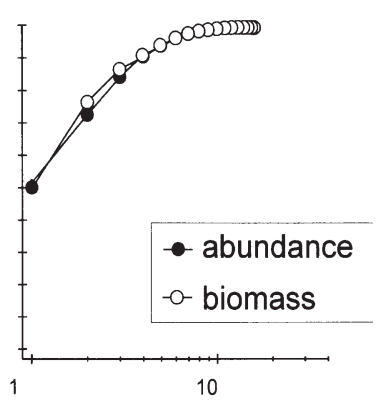

Beggiatoa community

Fig. 5. Abundance/biomass comparison plots of 'non-seep', Acharax, Calyptogena, and Beggiatoa communities. In the Beggiatoa community plot the biomass curve almost completely masks the abundance curve

increasing depth, but substantial concentrations of 7 to $25 \mathrm{mM}$ were only reached at 3 to $6 \mathrm{~cm}$ depth. A largely sulfide-free sediment layer of up to about $15 \mathrm{~cm}$ characterized the Acharax communities. At greater depths in the sediment, sulfide levels increased to a maximum value of $0.3 \mathrm{mM}$, although the levels varied significantly. Away from the seepage site, no sulfide was detected at the depth of the sediment cores.

The diffusive sulfide fluxes were extremely high above the gas hydrates covered by Beggiatoa mats, even ignoring any advective transport $(23 \pm 13 \mathrm{~mol}$ $\left.\mathrm{m}^{-2} \mathrm{yr}^{-1} ; \mathrm{n}=6\right)$; they were lower, but still high in absolute terms in the Calyptogena community $(6.6 \pm$ $\left.2.4 \mathrm{~mol} \mathrm{~m}^{-2} \mathrm{yr}^{-1} ; \mathrm{n}=6\right)$, and lowest in the Acharax sp. community $\left(0.05 \pm 0.05 \mathrm{~mol} \mathrm{~m}^{-2} \mathrm{yr}^{-1} ; \mathrm{n}=5\right)$.

\section{DISCUSSION}

\section{Do gas hydrates support distinct macrofaunal assemblages?}

The macrofauna in the Beggiatoa mats covering the gas hydrates consists nearly exclusively of species endemic to seeps and vents. Compared to the nonseep sites, this community has the lowest species diversity (Fig. 4) and the highest macrofaunal densities (Table 5). Compared to estimated mean macrofaunal densities reported for vesicomyid clam beds and inactive sediments (12518 specimens per $\mathrm{m}^{2}$ ) in water depths around $500 \mathrm{~m}$ on the northern Californian continental slope (Levin et al. 2000), macrofaunal densities in the Beggiatoa, Calyptogena, Acharax sp. and non-

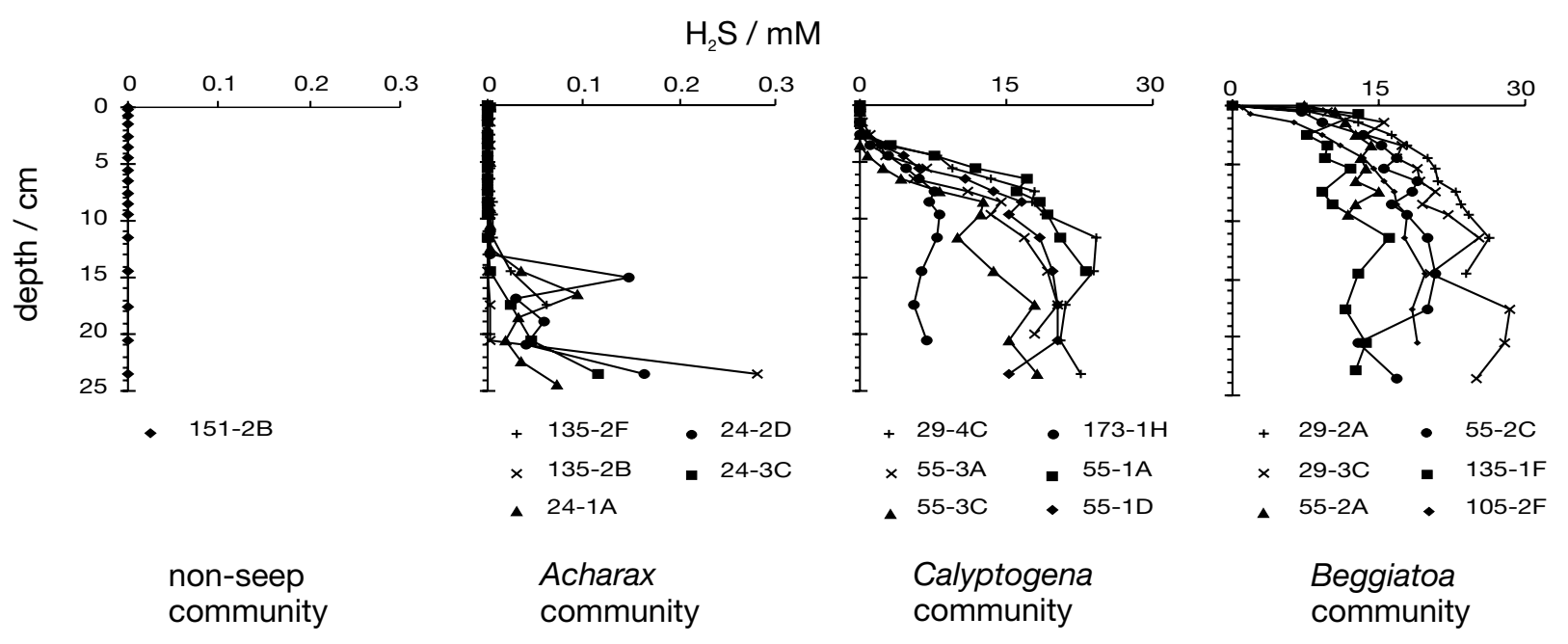

Fig. 6. Hydrogen sulfide concentrations in the pore water below 'non-seep', Acharax, Calyptogena, and Beggiatoa communities. Each symbol represents a multicore sample 
seep communities (8869, 4968, 1310, and 328 specimens $\mathrm{m}^{-2}$, respectively) are low. This difference can probably be largely attributed to differences in the sample processing between these studies, i.e. the more complete recovery of small species and inclusion of crustaceans in the study of Levin et al. (2000). However, oxygen concentrations in the bottom water overlaying Hydrate Ridge ( 0.40 to $\left.0.47 \mathrm{ml} \mathrm{l}^{-1}\right)$ and the nonseep reference stations (0.43 to $0.65 \mathrm{ml} \mathrm{l}^{-1}$ ) are lower than oxygen concentrations on the California slope $\left(0.76 \mathrm{ml} \mathrm{l}^{-1}\right)$. A reduction in macrofaunal abundance due to decreased oxygen concentrations has been shown in benthic habitats for different water depths (Hyland et al. 1991, Levin et al. 1991).

The heterotrophic macrofauna in the Calyptogena community surrounding the hydrate mounds is different from the macrofauna in the Beggiatoa community, as shown by the analyses of similarity. Species of Nuculana (Bivalvia), Pyropelta, Provanna, Hyalogyrina (Gastropoda) and Ampharetidae (Polychaeta) occur in higher densities in the Beggiatoa mat than in the Calyptogena community (Table 1). Thus it seems that the endemic species prefer the Beggiatoa community overlying the gas hydrates, and that these species emigrate to the surrounding chemoautotrophic communities. The relatively high abundance of the few invading species probably causes the reduction in diversity in the Calyptogena community (Fig. 4). This is in contrast to observations at cold seeps from the northern Californian slope, where species diversity was similar in clam beds compared to the reference sites (Levin et al. 2000).

Hydrate deposits in sediments forming mounds, which are covered by Beggiatoa mats and inhabited by polychaetes, have also been described from the Gulf of Mexico (Sassen et al. 1998, MacDonald et al. 1994, Fisher et al. 2000) and the Sea of Okhotsk (Zonenshayn et al. 1987, Kuznetsov \& Levenstein 1988). In these areas, the seep fauna surrounding the Beggiatoa communities is also different: In the Sea of Okhotsk, the thyasirid bivalve Conchocele sp. dominates (Zonenshayn et al. 1987), while in the Gulf of Mexico vestimentiferan tube worms, bathymodiolid mussels, and vesicomyid clams are typical (Carney 1994).

Interestingly, the gas hydrate site is most comparable to the hydrogen-sulfide-rich sediments found at the Guaymas Basin mounds, a sedimented hydrothermal vent field (Grassle et al. 1985). Here, the sediments are also covered by Beggiatoa mats adjacent to clam fields of Vesicomya gigas (Grassle et al. 1985, Grassle \& Petrecca 1994). The Guaymas and Hydrate Ridge sites share at least 4 species that are similar or closely related to each other.

In general, the communities dominated by thick Beggiatoa mats at the Cascadia margin, the Sea of
Okhotsk and the Gulf of Mexico as well as on the Guaymas Basin mounds appear to be similar to each other. The distinct macrofaunal communities in these areas seem to be the result of the occurrence of Beggiatoa mats, and thus are only indirectly linked to the hydrothermal fluids or dissociating gas hydrates.

\section{Is hydrogen sulfide the key factor regulating community structure in sulfidic environments?}

The highly different vertical sulfide gradients below the different communities (Fig. 6) strongly indicates the important role of sulfide availability in structuring community composition. The origin and distribution of hydrogen sulfide is closely connected to the occurrence of gas hydrate and the continuous oxidation of hydrate methane. The ascending methane is oxidized in a microbial mediated process coupled to sulfate reduction (Masuzawa et al. 1992, Wallmann et al. 1997, Boetius et al. 2000). The gas hydrate is an almost inexhaustible reservoir for methane supplied along the steep concentration gradient (Egorov et al. 1999). For estimation of the sulfide fluxes, only a first-order approximation of diffusive transport is used, whereas variable advective flow patterns (Tryon et al. 1999) and bioirrigation (Wallmann et al. 1997) may be superimposed and actually increase sulfide flux.

In addition, gas hydrate can have a direct influence on the infaunal species by affecting the physical properties of sediments. For example, millimeter-thin layers of hydrate were found a few millmeters to centimeters below the bacterial mats, and thus may have excluded fauna which usually occur in deeper sediments. Furthermore, because of their buoyancy, gas hydrates may be released from the seafloor and float up into the water column. It is not known how frequently such events occur and what their magnitudes are, but undoubtedly they would have a tremendous effect on the Beggiatoa community and the surrounding habitats, forcing repeated recolonization.

\section{Chemoautotrophy-dependent species}

The chemoautotroph Beggiatoa sp. and the chemoautotrophic symbiosis Calyptogena and Acharax depend directly on sulfide as an energy source (Nelson \& Jannasch 1983, Fisher 1990). In habitats with different sulfide settings (Fig. 6) these species occupy different niches. From our observations, we can make generalizations about the sulfidic environment of the chemoautotrophic species of filamentous sulfur bacteria as well as about the vesicomyid and solemyid bivalves. 
In the Beggiatoa community, sulfide concentrations increase very close to the sediment surface. The calculated sulfide flux of $23 \pm 13 \mathrm{~mol} \mathrm{~m}^{-2} \mathrm{yr}^{-1}$ is very high. The high sulfide flux may be also characteristic for the Beggiatoa habitat at the Guaymas Basin mounds where shimmering water over the sediment showed that pore fluid was seeping out; the fluids had sulfide concentrations of 7 to $15 \mathrm{mM}$ at $5 \mathrm{~cm}$ sediment depth (Jørgensen et al. 1990). The very high flux in the Beggiatoa community exposes the fauna on the sediment surface to elevated levels of sulfide, usually toxic to metazoans (Vetter et al. 1991). Furthermore, the high sulfide flux may cause temporal suboxic conditions in the near-bottom water, which already has low background oxygen concentrations $\left(0.40\right.$ to $\left.0.47 \mathrm{ml} \mathrm{l}^{-1}\right)$. Such variable conditions have also been described for the Guaymas Basin mounds (Gundersen et al. 1992), and may be tolerable for Beggiatoa, since this group of filamentous sulfur bacteria is believed to be capable of oxidizing sulfide by reducing its internally stored nitrate (Fossing et al. 1995, McHatton et al. 1996, Otte et al. 1999).

In the Calyptogena community, the maximum sulfide concentrations in sediments are similar to those of the Beggiatoa community (around $15 \mathrm{mM}$ ) but in the clam fields, the increase is at a depth of 3 to $4 \mathrm{~cm}$. This depth can be easily reached by the vermiform foot of the vesicomyid species through which hydrogen sulfide is taken up (Childress \& Fisher 1992). Furthermore, the Calyptogena species are able to adjust their position in the sediment, further controlling the sulfide concentrations encountered by the foot. At the cold seeps in Monterey Bay, the concentration of sulfide has been used to characterize the environments of the vesicomyid species $C$. pacifica and C. kilmeri (Barry et al. 1997). In the present study, the 2 Calyptogena species did not appear to occupy different sulfide microhabitats. The calculated sulfide flux in the vesicomyid clam fields $\left(6.6 \pm 2.4 \mathrm{~mol} \mathrm{~m}^{-2} \mathrm{yr}^{-1}\right)$ is about one-third that of the Beggiatoa community. Sulfide production rates of similar magnitude $\left(1.9 \mathrm{~mol} \mathrm{~m}^{-2} \mathrm{yr}^{-1}\right)$ have also been calculated for C. phaseoliformis clusters in the Aleutian Trench (Wallmann et al. 1997), and may be characteristic of environments inhabited by vesicomyid clams.

In the Acharax community, the sulfide concentration (0.1 to $0.3 \mathrm{mM})$ and flux $\left(0.05 \pm 0.05 \mathrm{~mol} \mathrm{~m}^{-2} \mathrm{yr}^{-1}\right)$ are 2 orders of magnitude less than in the Calyptogena community. Autotrophic growth of Solemya reidi, a shallow-water solemyid species has been demonstrated in laboratory experiments at comparable low sulfide concentrations $(0.1 \mathrm{mM}$ : Anderson et al. 1987). The sulfide profiles do not indicate steady diffusive flux into the Acharax-inhabited sediment layers (Fig. 6). This bivalve lives at the fringes of hydrate deposits and may satisfy its sulfide requirements by 'mining' the sediments, a behavior proposed for the solemyid $S$. borealis (Conway et al. 1992). The sulfide input into the sediment where this shallowwater solemyid lives is an order of magnitude higher (0.86 mol m $\mathrm{m}^{-2} \mathrm{yr}^{-1}$ : Conway et al. 1992) than fluxes calculated for the Acharax species. Both solemyid species live in habitats with a lower supply of sulfide than the vesicomyid clams (and Beggiatoa mats), which experience a high magnitude of vertical upward transport of sulfide.

\section{Heterotrophic species}

In contrast to the chemoautotrophy-dependent species, the heterotrophic species do not depend directly on hydrogen sulfide. Heterotrophic species endemic to seeps or species colonizing the seeps potentially profit from the high biomass of chemoautotrophicallyderived organic matter. The estimated biomass values at the reference stations $\left(10 \mathrm{~g} \mathrm{~m}^{-2}\right)$ compare well with expected values at that water depth based on global biomass distribution patterns (Rowe 1983). Despite the high availability of food, we did not find significant biomass differences of non-seep species (colonists) in the 3 communities compared to the reference sites. However, the differences in biomass of non-seep species between the Beggiatoa and Acharax communities is significant, and may be explained as follows: (1) The high biomass of non-seep species in the Acharax community $\left(31.8 \mathrm{~g} \mathrm{~m}^{-2}\right)$ may indicate a nutritional benefit at those sites which is not derived from hydrogen sulfide; (2) the low biomass of non-seep species in the Beggiatoa mats $\left(1.6 \mathrm{~g} \mathrm{~m}^{-2}\right)$ may be caused by the exclusion of non-seep species due to the very high sulfide concentrations at the sediment surface. Furthermore, the significantly higher biomass of seep endemic species in the Beggiatoa $\left(45.1 \mathrm{~g} \mathrm{~m}^{-2}\right)$ community compared to the Acharax community $\left(0.2 \mathrm{~g} \mathrm{~m}^{-2}\right)$ indicates that pre-adapted species in the sulfidic environment are actually able to exploit this chemosyntheticallyderived food source. Species in the Beggiatoa community must probably cope with temporal suboxic conditions. This would explain the high proportion of mobile fauna (Gastropoda, Nuculana sp., Polynoidae) and species which can rise appreciably into the bottom water such as the tube-dwelling ampharetid polychaetes.

The abundance/biomass comparison is a method applied in ecological studies to determine levels of disturbance (Clarke \& Warwick 1994) that result from chemical (pollution, oxygen limitation, very high organic matter input) or physical (gas hydrate release) impacts. When a community is highly disturbed, large 
and long-lived 'conservative' species become less favored, and small and short-lived 'opportunistic' species become dominant (Clarke \& Warwick, 1994). Based on the results from the abundance/biomass comparison (Fig. 5), the Beggiatoa community exhibits such a pattern of disturbance. Another characteristic of disturbed communities observed in this study and other faunal assemblages associated with high sulfide fluxes is reduced species diversity, with the relative abundance skewed in the direction of a few, most common species (Grassle \& Petrecca 1994).

\section{CONCLUSIONS}

At hydrate ridge, the sulfide concentrations and the sulfide fluxes in the sediment overlaying the gas hydrate deposits were high and sustain a community dominated by Beggiatoa mats and an endemic macrofauna. High sulfide fluxes may characterize the Beggiatoa communities, which are similar in very different geological settings such as the gas hydrate deposits and sedimented hydrothermal mounds. The sulfide flux in the Calyptogena community estimated in this study and sulfide production rates at clam beds in the Aleutian trench (Wallmann et al. 1997) are in the same order of magnitude and may be characteristic of vesicomyid communities which are regularly found at cold seeps at active and passive continental margins in water depths below 300 m (Sibuet and Olu 1998). The calculated sulfide fluxes in the solemyid habitat in both shallow-water and deep-water, is orders of magnitude lower than in the vesicomyid clam beds.

Reducing sedimented environments are diverse, ranging from hydrothermal vents, cold seeps, gas hydrates, mud volcanoes, sediments below upwelling areas, and decaying whale carcasses to pulpmill effluent sites. While the geology and geochemistry are dramatically different in this areas, striking similarities in community structure exist at the family level. We are beginning to understanding the influence of abiotic parameters (e.g. oxygen, sulfide, methane levels) in structuring these communities. The results of this study suggest that sulfide flux, rather than sulfide concentration per se, may be an important factor governing the distribution patterns of major groups such as sulfur-oxidizing filamentous bacteria, vesicomyids, and solemyids in deeper water (>300 m depth) environments. Generalizations regarding the relationship between sulfide concentration and the occurrence of these groups do not seem possible, since sulfide levels where these groups are found vary considerably. Alternatively, we postulate that sulfide flux may be an environmental parameter that accounts for faunal distributions in diverse geological settings.
Acknowledgements. We would like to thank the crews of RV 'Atlantis' and RV 'Sonne' and the pilots of DSV 'Alvin' for their highly professional support. We are indebted to the officers of RV 'Sonne' for contributing the first-class navigational capabilities essential to this study. We are grateful to N. Aberle, F. Appel, B. Bannert, B. Domeyer, B. Heitmann, A. Heuser, A. Kaehler, F. Kulescha, M. Nimser, A. Petersen, O. Pfannkuche, W. Queisser, S. Sommer, and U. Witte for their enthusiasm and indispensable help at sea. We thank W. Weinrebe for the processing of the bathymetric data. A. Boetius, G. Bohrmann, E. Hütten, D. Piepenburg and K. Wallmann improved an initial version of this manuscript considerably. We especially thank A. Warén, G. Coan, T. Waller, J. Barry, J. Blake, B. Hilbig for species determinations. Comments from 4 anonymous reviewers improved the manuscript. The projects were funded by the BMBF 03G0143A, BMBF 03F0236B, and NSF OCE-973315503. This is publication no. 13 of SFB 574 'Volatiles and Fluids in Subduction Zones' at Kiel University

\section{LITERATURE CITED}

Allen JA (1993) A new deep-water hydrothermal species of Nuculana (Bivalvia: Protobranchia) from the Guaymas Basin. Malacologia 35:141-151

Anderson AE, Childress JJ, Favuzzi JA (1987) Net uptake of $\mathrm{CO}_{2}$ driven by sulphide and thiosulphate oxidation in the bacterial symbiont-containing clam Solemya reidi. J Exp Biol 133:1-31

Barry JP, Kochevar RE (1998) A tale of two clams: differing chemosynthetic life styles among vesicomyids in Monterey Bay cold seeps. Cah Biol Mar 39:329-331

Barry JP, Green HG, Orange DL, Baxter CH and 5 others (1996) Biological and geological characteristics of cold seeps in Monterey Bay, California. Deep-Sea Res I 43: 1739-1762

Barry JP, Kochevar RE, Baxter CH (1997) The influence of pore-water chemistry and physiology in the distribution of vesicomyid clam at cold seeps in Monterey Bay: implications for patterns of chemosynthetic community organization. Limnol Oceanogr 42:318-328

Beninger PG, Le Pennec M (1997) Reproductive characteristics of a primitive bivalve from a deep-sea reducing environment: giant gametes and their significance in Acharax alinae (Cryptodonta: Solemyidae). Mar Ecol Prog Ser 157: 195-206

Blake JA (1985) Polychaeta from the vicinity of deep-sea geothermal vents in the eastern Pacific I: Euphrosinidae, Phyllodocidae, Hesionidae, Nereididae, Glyceridae, Dorvilleidae, Orbiniidae and Maldanidae. Bull Biol Soc Wash 6:67-101

Boetius A, Ravenschlag K, Schubert CJ, Rickert D and 6 others (2000) Microscopic identification of a microbial consortium apparently mediating anaerobic methane oxidation above marine gas hydrate. Nature 407:623-626

Bohrmann G, Linke P, Suess E, Pfannkuche O (2000) Cruise report SO 143, TECFLUX. GEOMAR, Kiel

Boudreau BP (1997) Diagenetic models and their implementations. Springer-Verlag, New York

Brooks JM, Field M, Kennicutt MC (1991) Observations of gas hydrates in marine sediments, offshore northern California. Mar Geol 96:103-109

Carney RS (1994) Consideration of the oasis analogy for chemosynthethic communities at Gulf of Mexico hydrocarbon vents. Geo-Mar Lett 14:149-159

Childress JJ, Fisher CR (1992) The biology of hydrothermal 
vent animals: physiology, biochemistry and autotrophic symbiosis. Oceanogr Mar Biol Annu Rev 30:337-441

Clarke KR, Warwick RM (1994) Change in marine communities: an approach to statistical analysis and interpretation. Natural Environment Research Council, Plymouth, UK

Conway NM, Howes BL, McDowell Capuzzo J, Turner RD, Cavanaugh CM (1992) Characterization and site description of Solemya borealis (Bivalvia: Solemyidae), another bivalve-bacteria symbiosis. Mar Biol 112:601-613

Egorov AV, Crane K, Vogt PR, Rozhkov AN (1999) Gas hydrates that outcrop the sea floor: stability models. GeoMar Lett 19:89-96

Felbeck H, Childress JJ, Somero GN (1981) Calvin-Benson cycle and sulphide oxidation enzymes in animals from sulphide-rich habitats. Nature 293:291-293

Feller RJ, Warwick RM (1988) Energetics. In: Higgins RP, Thiel $\mathrm{H}$ (eds) Introduction to the study of meiofauna. Smithonian Institution Press, Washington, DC, p 181-196

Fiala-Médioni A, Boulègue $\mathrm{J}$, Ohta $\mathrm{S}$, Felbeck H, Mariotti A (1993) Source of energy sustaining the Calyptogena populations from deep trenches in subduction zone off Japan. Deep-Sea Res I 40:1241-1258

Fisher CR (1990) Chemoautotrophic and methanotrophic symbioses in marine invertebrates. Rev Aquat Sci 2: $399-436$

Fisher CR, Donald IRM, Sassen R, Young CM and 5 others (2000) Methane ice worms: Hesiocaeca methanicola colonizing fossil fuel reserves. Naturwissenschaften 87: $184-187$

Fossing H, Gallardo VA, Jørgensen BB, Hüttel M and 11 others (1995) Concentration and transport of nitrate by the mat-forming sulphur bacterium Thioploca. Nature 374: $713-715$

Ginsburg GD, Soloviev VA, Cranston RE, Lorenson TD, Kvenvolden KA (1993) Gas hydrates from the continental slope, offshore Sakhalin Island, Okhotsk Sea. Geo-Mar Lett 13: 41-48

Grasshoff M, Ehrhardt K, Kremling K (1983) Methods of seawater analysis. Verlag Chemie, Weinheim

Grassle JF, Petrecca R (1994) Soft-sediment hydrothermal vent communities of Escanaba Trough. In: Morton JL, Zierenberg RA, Reiss CA (eds) Geologic, hydrothermal, and biologic studies at Escanaba Trough, Gorda Ridge, Offshore Northern California. US Geological Survey, Menlo Park, California, p 327-335

Grassle JF, Brown-Leger LS, Morse-Porteous L, Petrecca R, Williams I (1985) Deep-sea fauna of sediments in the vicinity of hydrothermal vents. Biol Soc Wash Bull 6: $443-452$

Gundersen JK, Jørgensen BB, Larsen E, Jannasch HW (1992) Mats of giant sulphur bacteria on deep-sea sediments due to fluctuating hydrothermal flow. Nature 360:454-456

Hovland H, Judd AG (1988) Seabed pockmarks and seepages. Graham \& Trotman, Oxford

Hyland J, Baptiste E, Campbell J, Kennedy J, Kropp R, Williams S (1991) Macroinfaunal communities of the Santa Maria Basin on the California outer continental shelf and slope. Mar Ecol Prog Ser 78:147-161

Jørgensen BB, Zawacki LX, Jannasch HW (1990) Thermophilic bacterial sulfate reduction in deep-sea sediments at the Guaymas Basin hydrothermal vent side (Gulf of California). Deep-Sea Res Part I Oceanogr Res Pap 37: 695-710

Juniper SK, Tunnicliffe V, Southward EC (1992) Hydrothermal vents in turbidite sediments on a Northeast Pacific spreading centre: organisms and substratum at an ocean drilling site. Can J Zool 70:1792-1809
Kulm LD, Suess E, Moore JC, Carson B, Lewis BT, Ritger SD, Kadko DC, Thornburg TM, Embley RW, Rugh WD, Massoth GJ, Langseth MG, Cochrane GR, Scamann RL (1986) Oregon subduction zone: venting, fauna, and carbonates. Science 231:561-566

Kuznetsov AP, Levenstein RY (1988) Pavelius uschakovi gen. et sp. n. (Polychaeta, Ampharetidae) from the area of the Paramushir gas hydrate vent in the Sea of Okhotsk (in Russian). Zool Zh 67:819-825

Lee RW, Robinson JJ, Cavanaugh CM (1999) Pathways of inorganic nitrogen assimilation in chemoautotrophic bacteria-marine invertebrate symbioses: expression of host and symbiont glutamine synthetase. J Exp Biol 202: $289-300$

Levin LA, Huggett CL, Wishner KF (1991) Control of deep-sea benthic community structure by oxygen and organicmatter gradients in the eastern Pacific Ocean. J Mar Res 49:763-800

Levin LA, James DW, Martin CM, Rathburn AE, Harris LH, Michener RH (2000) Do methane seeps support distinct macrofaunal assemblages? Observations on community structure and nutrition from the northern California slope and shelf. Mar Ecol Prog Ser 208:21-39

Linke P, Suess E, Torres M, Martens V, Rugh WD, Ziebis W, Kulm LD (1994) In situ measurement of fluid flow from cold seeps at active continental margins. Deep-Sea Res I 41:721-739

Lozán JL (1998) Angewandte Statistik für Naturwissenschaftler. Parey, Berlin

MacDonald IR, Guinasso NL, Sassen R, Brooks JM, Lee L, Scott KT (1994) Gas hydrate that breaches the sea floor on the continental slope of the Gulf of Mexico. Geology (Boulder) 22:699-702

Masuzawa T, Handa N, Kitagawa H, Kusakabe M (1992) Sulfate reduction using methane in sediments beneath a bathyal 'cold-seep' giant clam community off Hatsushima Island, Sagami Bay, Japan. Earth Planet Sci Lett 110: $39-50$

McHatton SC, Barry JP, Jannasch HW, Nelson DC (1996) High nitrate concentrations in vacuolate, autotrophic marine Beggiatoa spp. Appl Environ Microbiol 62: 954-958

Nelson DC, Jannasch HW (1983) Chemoautotrophic growth of marine Beggiatoa in sulfide-gradient cultures. Arch Microbiol 136:262-269

Olu K, Sibuet M, Harmegnies F, Foucher JP, Fiala-Médioni A (1996) Spatial distribution of diverse cold seep communities living on various diapiric structures of the southern Barbados prism. Prog Oceanogr 38:347-376

Otte S, Kuenen JG, Nielsen LP, Paerl HW and 6 others (1999) Nitrogen, carbon, and sulphur metabolism in natural Thioploca samples. Appl Environ Microbiol 65:3148-3157

Paull CK, Ussler WI, Borowski WS, Spiess FN (1995) Methanerich plumes on the Carolina continental rise: associations with gas hydrates. Geology (Boulder) 23:89-92

Petrecca RF, Grassle JF (1990) Notes on fauna from several deep-sea hydrothermal vent and cold seep soft-sediment communities. In: McMurray GR (ed) Gorda Ridge. Springer-Verlag, New York, p 281-283

Rowe GT (1983) Biomass and production of the deep-sea macrobenthos. In: Rowe GT (ed) The sea. John Wiley, New York, p 97-121

Sassen R, MacDonald IR, N. R. Guinasso J, Joye S and 5 others (1998) Bacterial methane oxidation in sea-floor gas hydrate: significance to life in extreme environments. Geology (Boulder) 26:851-854

Sibuet M, Olu K (1998) Biogeography, biodiversity and fluid 
dependence of deep-sea cold-seep communities at active and passive margins. Deep-Sea Res II 45:517-567

Suess E, Carson B, Ritger SD, Moore JC, Jones ML, Kulm LD, Cochrane GR (1985) Biological communities at vent sites along the subduction zone off Oregon. Biol Soc Wash Bull 6:475-484

Suess E, Torres ME, Bohrmann G, Collier RW and 7 others (1999) Gas hydrate destabilization: enhanced dewatering, benthic material turnover and large methane plumes at the Cascadia convergent margin. Earth Planet Sci Lett 170:1-15

Torres M, Bohrmann G, Brown K, de Angelis M and 5 others (1999) Geochemical observations on Hydrate Ridge, Cascadia Margin during R/V-ATLANTIS-cruise AT3-35b. Oregon State University, Corvallis, OR

Tryon MD, Brown KM, Torres ME, Trehu AM, McManus J, Collier RW (1999) Measurements of transience and down-

Editorial responsibility: Otto Kinne (Editor),

Oldendorf/Luhe, Germany ward fluid flow near episodic methane gas vents, Hydrate Ridge, Cascadia. Geology (Boulder) 27:1075-1078

Vetter RD, Powell MA, Somero GN (1991) Metazoan adaptations to hydrogen sulphide. In: Bryant C (ed) Metazoan life without oxygen. Chapman \& Hall, London, p 109-128

Wallmann K, Linke P, Suess E, Bohrmann G and 6 others (1997) Quantifying fluid flow, solute mixing, and bigeochemical turnover at cold vents of the eastern Aleutian subduction zone. Geochim Cosmochim Acta 61: 5209-5219

Warén A, Bouchet P (2001) Gastropoda and Monoplacophora from hydrothermal vents and seeps; new taxa and records. Veliger 44:116-231

Zonenshayn LP, Murdmaa IO, Baranov BV, Kuznetsov AP and 8 others (1987) An underwater gas source in the Sea of Okhotsk west of Paramushir island. Oceanology 27: 598-602

Submitted: January 15, 2000; Accepted: May 31, 2001 Proofs received from author(s): March 22, 2002 